\title{
Physicochemical Properties of Moringa oleifera Leaves Grown in Valencian Community (Spain) ${ }^{\dagger}$
}

\author{
María D. Ortolá ${ }^{1, * \mathbb{D}}$, María Luisa Castelló ${ }^{1} \mathbb{D}$, Maria C. Etchevers ${ }^{1}$, Francisco José García-Mares ${ }^{2}$ and \\ María D. Soriano ${ }^{3}$
}

1 Institute of Food Engineering for Development, Universitat Politècnica de València, Camino de Vera s/n, 46022 Valencia, Spain; mcasgo@upv.es (M.L.C.); coni.etchevers@live.cl (M.C.E.)

2 Department of Hydraulic Engineering and Environment, Universitat Politècnica de València, Camino de Vera s/n, 46022 Valencia, Spain; fjgarcia@gmf.upv.es

3 Department of Plant Production, Universitat Politècnica de València. Camino de Vera s/n, 46022 Valencia, Spain; asoriano@prv.upv.es

* Correspondence: mdortola@tal.upv.es

+ Presented at the III Conference la ValSe-Food and VI Symposium Chia-Link Network, online, 15-17 November 2021.

check for updates

Citation: Ortolá, M.D.; Castelló, M.L.; Etchevers, M.C.; García-Mares, F.J.; Soriano, M.D. Physicochemical Properties of Moringa oleifera Leaves Grown in Valencian Community (Spain). Biol. Life Sci. Forum 2021, 8, 4. https://doi.org/10.3390/

blsf2021008004

Academic Editors: Loreto Muñoz and Claudia M. Haros

Published: 15 December 2021

Publisher's Note: MDPI stays neutral with regard to jurisdictional claims in published maps and institutional affiliations.

Copyright: (c) 2021 by the authors. Licensee MDPI, Basel, Switzerland. This article is an open access article distributed under the terms and conditions of the Creative Commons Attribution (CC BY) license (https:// creativecommons.org/licenses/by/ $4.0 /)$.

\begin{abstract}
Moringa oleifera is a foliated tree widely cultivated in tropical latitudes, which is highly adaptable to climatic conditions and dry soils. Every part of the plant has nutritional, therapeutic or industrial benefits. This is due to its phytochemicals such as glucosinolates, phenolic compounds, alkaloids, terpenoids and tannins, high values of crude protein, carbohydrates, starch and lipids. In addition, the use of the leaves has increased considerably by the agro-food and biochemical industries since they are a valuable source of dietary proteins and essential amino acids. This work aimed to characterize three types of leaf from Moringa oleifera seeds with different origins (Thai (C1), Ghana (C2) and India (C3)), grown in the same plot, but with different cultural practices (intended for leaf production (C1 and $\mathrm{C} 2$ ) or sheath production (C3). For this, water content and optical properties were determined in the fresh leaves. Later the leaves were dried $\left(50{ }^{\circ} \mathrm{C}\right.$ for $\left.8 \mathrm{~h}\right)$ and pulverized, analyzing their water content, antioxidant capacity, color and amino acid content. No significant differences were observed in fresh leaves in terms of humidity and color. In dry powder, a higher antioxidant capacity was registered in moringa type $\mathrm{C} 2$, with a\% DPPH inhibition of $83.7 \%$, although in all cases, it exceeded $60 \%$, showing the high persistence of the antioxidants after drying. Serine, glutamic acid and alanine were the major amino acids with values of $373 \pm 78,301 \pm 51$ and $248 \pm 9 \mathrm{mg} / 100 \mathrm{~g}$ of powder, respectively, without influencing the applied field treatment or origin.
\end{abstract}

Keywords: amino acid content; antioxidant capacity; color; Moringa oleifera

\section{Introduction}

The opportunity of diversifications offered by the agri-food sector implies the need to address the development of certain crops due to the new climatic conditions. The increasing demand for protein around the world means a great challenge to find sustainable alternative protein sources that have a high biological value [1]. Plants and green leaves have enormous potential for the production of protein concentrates.

Moringa oleifera is a foliated tree widely cultivated in tropical latitudes, which shows high adaptability to climatic conditions and dry soils [2]. It is a native species of South Asia, which grows at the foot of the Himalayas, from the northeast of Pakistan to the north of Bengal in India, presenting various nutritional, therapeutic or industrial benefits [3,4]. In particular, the leaves have been investigated as a valuable source of dietary protein and essential amino acids, and their use as an ingredient in livestock and human nutrition has been promoted [5]. 
In many parts of the world, including Africa, the use of M. oleifera as a nutritious food is on the rise. However, in developed countries, its use as a food ingredient is not well known. Its cultivation is not widespread in these regions either, despite its easy adaptation to hot climates (for example, the Mediterranean area). For that reason, this study was focused on the compositional and physicochemical analysis of different types of moringa leaves grown in Valencia. In addition, and in view of their possible incorporation into food matrices, the dry leaves were also characterized.

\section{Materials and Methods}

Three types of Moringa oleifera with different origins were used as raw material: Thailand (C1), Ghana (C2) and India (C3). They were grown in an experimental plot of the Universitat Politècnica de València, and their leaves were collected at the end of September 2020. The C1 and C2 types had cultural practices in the plants intended for leaf production, while the C3 was prepared to produce pods. Part of the leaves were dehydrated in a tray dryer with hot air at $50{ }^{\circ} \mathrm{C}$ for $8 \mathrm{~h}$. Then, they were pulverized in a grinder (Thermomix, TM31, Vorwerk, Wupertal, Germany) for $3 \mathrm{~min}$. The powder was sieved with a $0.5 \mathrm{~mm}$ sieve and stored in glass jars wrapped in aluminum foil and stored on dark shelves at room temperature for further experiments.

\section{Water Content, Antioxidant Capacity, Optical Properties and Amino Acid Content}

Water content was obtained by a gravimetric method (AOAC, 20.013, 2000) until a constant weight of the samples was reached after drying at $60{ }^{\circ} \mathrm{C}$ (VACIOTEM-T, J.P. Selecta Spain). An adaptation of the spectrophotometric DPPH method [6] was used to analyze the antioxidant capacity.

Color of moringa fresh leaves and powder was determined using a spectrocolorimeter (Konica Minolta, Inc., model CM-3600d, Tokyo, Japan). The results were expressed according to the CIE L*a*b* reference system with the D65 Standard Illuminant and $10^{\circ}$ Standard Observer.

An EZ-Faast amino acid kit (Phenomenex, Torrance, CA, USA) was used to carry out the amino acid analyses [7].

\section{Results and Discussion}

The water content of fresh moringa leaves was $65 \pm 3 \%$, without significant differences between them. After drying (Figure 1A), the moringa of Thai origin (C1) registered the highest value of water content, with no significant differences from the other types of moringa (C2 and $\mathrm{C} 3$ ). In this sense, $\mathrm{C} 1$ requires a longer drying time despite having a vegetative level similar to that of $\mathrm{C} 2$, since both are used for the production of leaves, while moringa C3 is of the arboreal type for the production of pods.
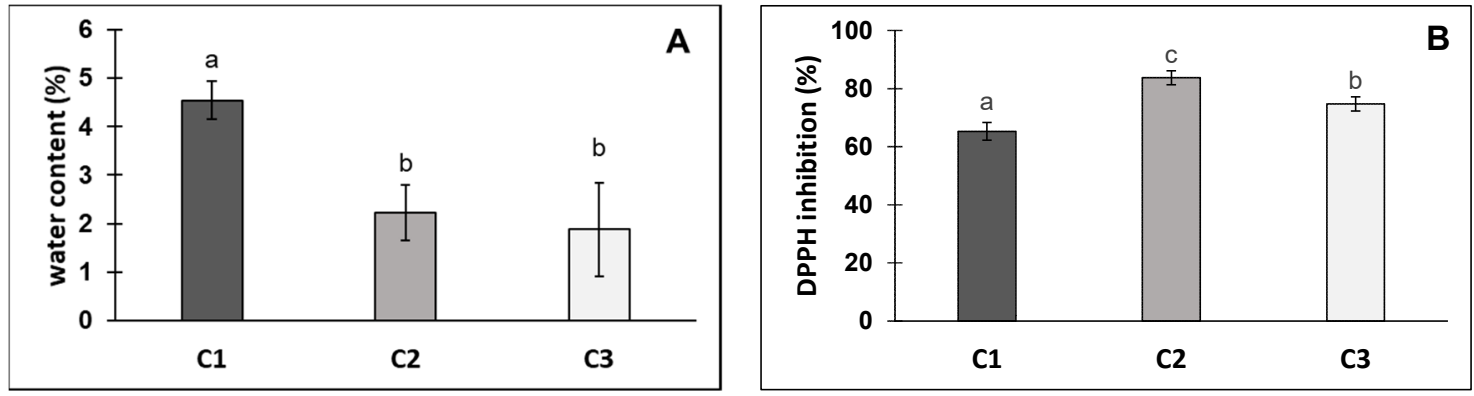

Figure 1. (A) water content and (B) antioxidant activity expressed as percentage of DPPH inhibition for different dehydrated moringa leaves (C1, C2 and C3). Equal letters indicate correlations coefficients statistically different $(p<0.01)$.

In all cases, DPPH inhibition (Figure 1B) was greater than $60 \%$, highlighting moringa C2 $(83 \pm 2 \%)$, with similar antioxidant capacity reported in the Mexican [8] and fresh 
Indonesian leaves. Therefore, the origin of plants would mainly influence the concentration of bioactive compounds and their antioxidant capacity.

\subsection{Optical Properties}

Figure 2 show $\mathrm{a}^{*}$ and $\mathrm{b}^{*}$ coordinates location in the chromatic plane of the fresh and dried leaves. As can be seen, regardless of the origin, the moringa powder presented greater purity of color than the fresh leaves because of the higher value in the coordinate $b^{*}$. This behavior shows that the drying stage involves the loss of green tones, enhancing the yellows, due to the chlorophyll degradation and the formation of pheophytins [9]. In relation to the differences registered between the upper side and the underside of the leaves, as expected, the upper side presented higher values of $a^{*}$ and lower values of $b^{*}$, giving evidence of coloration with a darker greenish intensity than that of the underside.

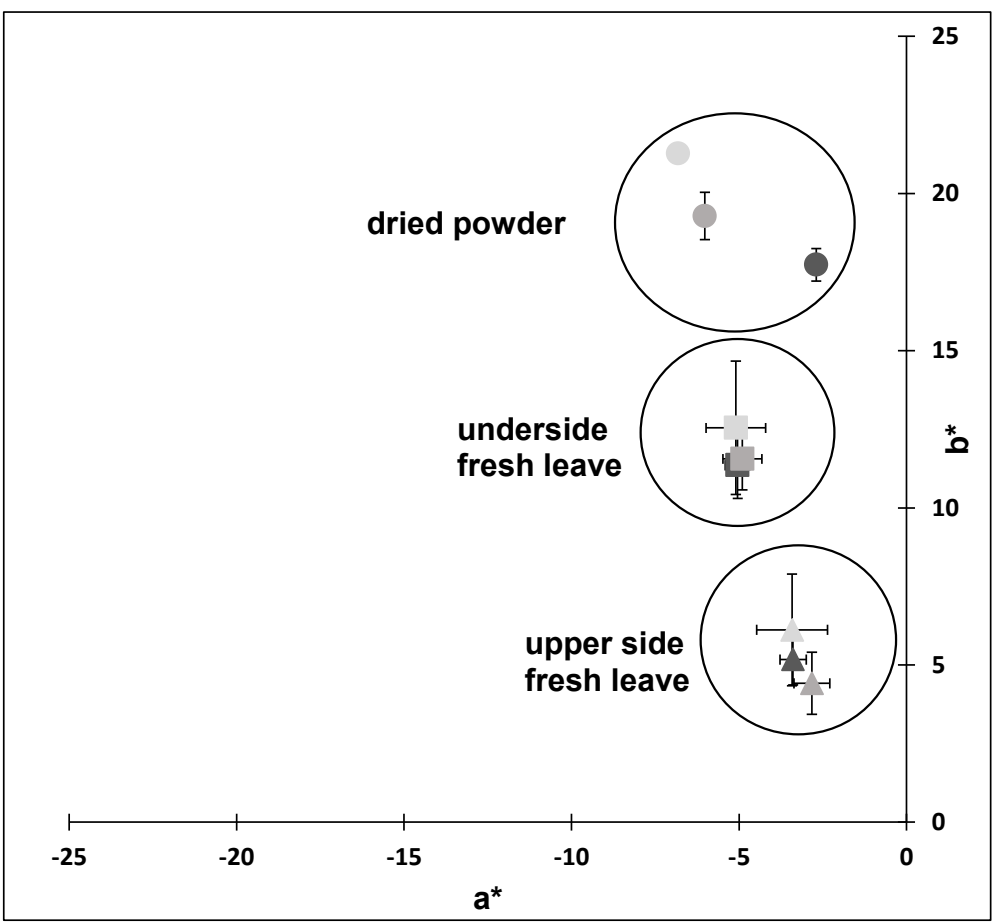

Figure 2. $\mathrm{a}^{*}$ and $\mathrm{b}^{*}$ coordinates location in the chromatic plane of the fresh and dried leaves. Dried powder: $\bullet \mathrm{C} 1, \bullet \mathrm{C} 2, \cdot \mathrm{C} 3$; upper side fresh leaves: $\triangle \mathrm{C} 1, \triangle \mathrm{C} 2, \triangle \mathrm{C} 3$; underside fresh leaves: $\square \mathrm{C} 1, \square \mathrm{C} 2$, C3.

\subsection{Amino Acid Content}

These moringa powders contained seven essential amino acids and were very rich in serine, glutamic acid and alanine without showing significant differences between the evaluated samples (Figure 3). The amount of glutamic acid content was similar to the reported value in dried moringa leaves grown in Greece [10] and South Africa [11]. However, the high serine content in these samples contrasted with concentrations found in other studies, where it was not one of the majority amino acids [10-12]. Furthermore, moringa intended for pod production (C3) showed the highest concentrations in some of the minor amino acids (threonine and asparagine). The high concentration of hydrophobic amino acids (alanine, leucine, isoleucine, phenylalanine and methionine) and acidic amino acid (glutamic acid) could be related to the high antioxidant power of moringa leaves [13]. 


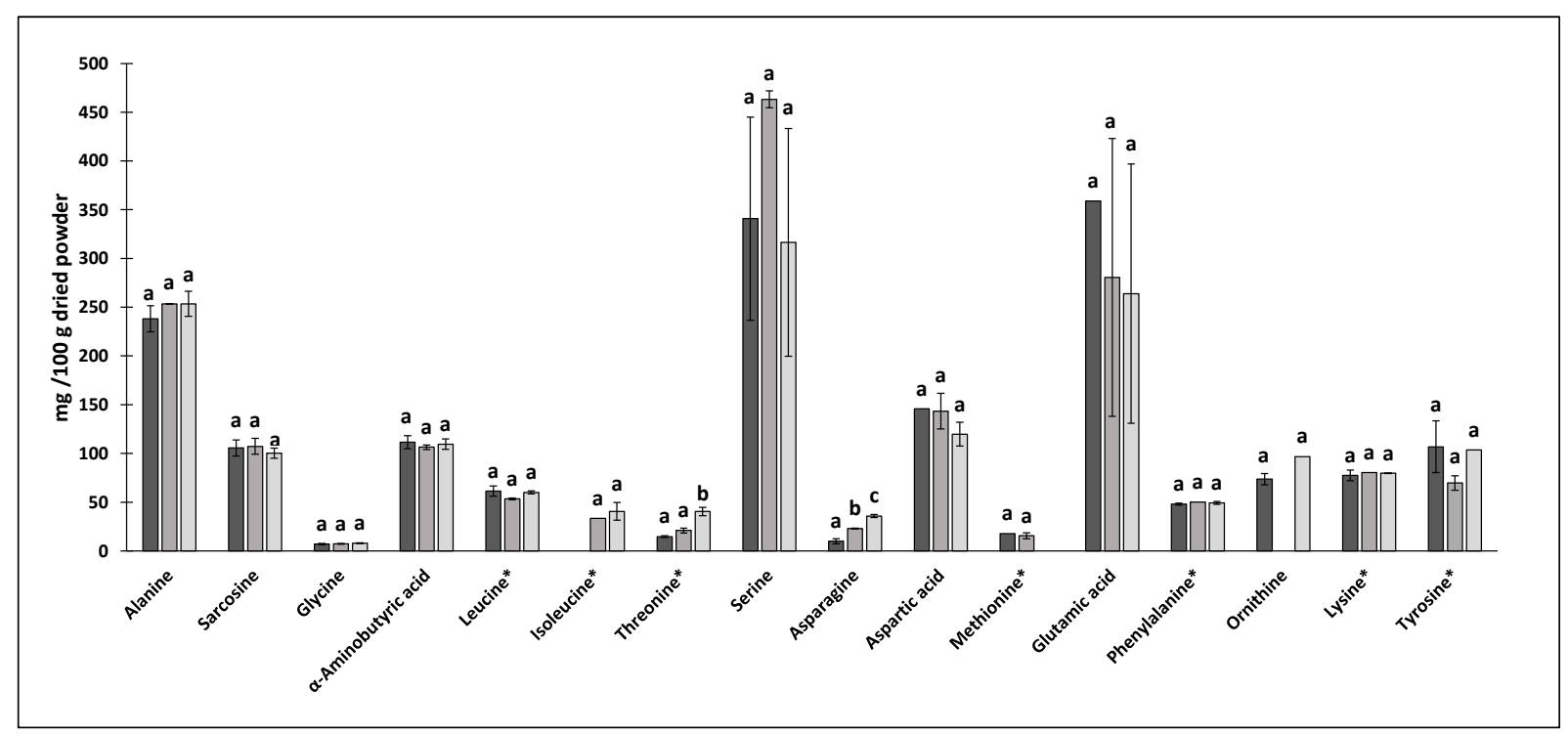

Figure 3. Amino acid content (* essential) of moringa powder: C1 (dark grey), C2 (intermediate grey) and C2 (light gray). Equal letters for the same amino acid indicate homogenous group in ANOVA $(p<0.01)$.

\section{Conclusions}

Fresh moringa leaves studied from seeds of different origins and with different cultural practices did not show significant differences in optical properties. Once dehydrated, the powders obtained did not show significant differences in the amino acid profile either, the most abundant being serine, glutamic acid and alanine. However, the plants destined for the production of leaves from Ghana (C2) had a higher antioxidant capacity. In addition, the moringa powder showed greater purity of color than the fresh leaves due to the loss of chlorophyll, although the greenish coloration persisted.

Institutional Review Board Statement: Not applicable.

Informed Consent Statement: Not applicable.

Acknowledgments: This work was supported by the grant Ia ValSe-Food-CYTED (119RT0567) and project Nuevos Cultivos Frente al Cambio climático: Moringa y Estevia (MORESVIA) (AGCOOP_A/2018/026) funded by Generalitat Valenciana.

\section{References}

1. McCarty, M.F.; Barroso-Aranda, J.; Contreras, F. The low-methionine content of vegan diets may make methionine restriction feasible as a life extension strategy. Med. Hypotheses 2009, 72, 125-128. [CrossRef] [PubMed]

2. Okuda, T.; Baes, A.U.; Nishijima, W.; Okada, M. Isolation and characterization of coagulant extracted from Moringa oleifera seed by salt solution. Water Res. 2001, 35, 405-410. [CrossRef]

3. Aderinola, T.A.; Alashi, A.M.; Nwachukwu, I.D.; Fagbemi, T.N.; Enujiugha, V.N.; Aluko, R.E. In vitro digestibility, structural and functional properties of Moringa oleifera seed proteins. Food Hydrocoll. 2020, 101, 105574. [CrossRef]

4. Nouman, W.; Anwar, F.; Gull, T.; Newton, A.; Rosa, E.; Domínguez-Perles, R. Profiling of polyphenolics, nutrients and antioxidant potential of germplasm's leaves from seven cultivars of Moringa oleifera Lam. Ind. Crops Prod. 2016, 83, 166-176. [CrossRef]

5. Amaglo, N.K.; Bennett, R.N.; Lo Curto, R.B.; Rosa, E.A.S.; Lo Turco, V.; Giuffrida, A.; Lo Curto, A.; Crea, F.; Timpo, G.M. Profiling selected phytochemicals and nutrients in different tissues of the multipurpose tree Moringa oleifera L., grown in Ghana. Food Chem. 2010, 122, 1047-1054. [CrossRef]

6. Turkmen, N.; Sari, F; Velioglu, Y.S. The effect of cooking methods on total phenolics and antioxidant activity of selected green vegetables. Food Chem. 2005, 93, 713-718. [CrossRef]

7. Periche, A.; Koutsidis, G.; Escriche, I. Composition of antioxidants and amino acids in stevia leaf infusions. Plant Foods Hum. Nutr. 2014, 69, 1-7. [CrossRef] [PubMed]

8. Cuellar-Nuñez, M.L.; Luzardo-Ocampo, I.; Campos-Vega, R.; Gallegos-Corona, M.A.; González de Mejía, E.; Loarca-Piña, G. Physicochemical and nutraceutical properties of moringa (Moringa oleifera) leaves and their effects in an in vivo AOM/DSSinduced colorectal carcinogenesis model. Food Res. Int. 2018, 105, 159-168. [CrossRef] [PubMed] 
9. Sledz, M.; Witrowa-Rajchert, D. Influence of microwave-convective drying of chlorophyll content and colour of herbs. Acta Agrophysica 2012, 19, 865-876.

10. Lalas, S.; Athanasiadis, V.; Karageorgou, I.; Batra, G.; Nanos, G.D.; Makris, D.P. Nutritional characterization of leaves and herbal tea of moringa oleifera cultivated in Greece. J. Herbs Spices Med. Plants 2017, 23, 320-333. [CrossRef]

11. Moyo, B.; Masika, P.J.; Hugo, A.; Muchenje, V. Nutritional characterization of Moringa (Moringa oleifera Lam.) leaves. Afr. J. Biotechnol. 2011, 10, 12925-12933. [CrossRef]

12. Castillo-López, R.I.; León-Félix, J.; Angulo-Escalante, M.Á.; Gutiérrez-Dorado, R.; Muy-Rangel, M.D.; Heredia, J.B. Nutritional and phenolic characterization of moringa Oleifera leaves grown in Sinaloa, México. Pakistan J. Bot. 2017, 49, 161-168.

13. Natsir, H.; Wahab, A.W.; Budi, P.; Dali, S.; Arif, A.R. Amino acid and mineral composition of moringa oleivera leaves extract and its bioactivity as antioxidant. J. Phys. Conf. Ser. 2019, 1317, 012030. [CrossRef] 